\title{
Static Fatigue and Fracture Toughness of Mullite Ceramics at $1200^{\circ} \mathrm{C}$
}

\author{
Yoshitaka KUBOTA, Masahiro ASHIZUKA* and Eiichi ISHIDA* \\ Tsukuba Research Laboratory, Tosoh Co., Ltd., 43, Miyukigaoka, Tsukuba-shi, Ibaraki 305 \\ *Department of Materials Science and Engineering, Faculty of Engineering, Kyushu Institute of Technology, \\ 1-1, Sensui-cho, Tobata-ku, Kitakyushu-shi 804
}

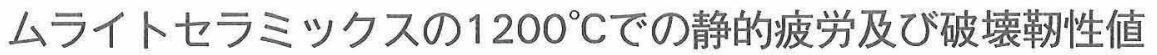 \\ 窪田吉孝・芦塚正博* ・石田英一* \\ 東ソー(株)筑波研究所, 305 荻城県つくば市御幸が丘 43 \\ *九州工業大学工学部物質工学科材料工学教室, 804 北九州市戸畑区仙水町 1-1}

[Received December 27, 1993; Accepted July 14, 1994]

\begin{abstract}
The fatigue behavior for mullite ceramics containing 71,72 and $74 \mathrm{wt} \% \mathrm{Al}_{2} \mathrm{O}_{3}$ (71A, $72 \mathrm{~A}$ and $74 \mathrm{~A}$ ) was measured at $1200^{\circ} \mathrm{C}$ by the static fatigue technique. The fracture toughness was evaluated from the slow crack growth magnitude (fatigue fracture surface) combined with the applied stress. The crack growth parameter $(N)$ of $71 \mathrm{~A}, 72 \mathrm{~A}$ and $74 \mathrm{~A}$ was $17,23-24$ and 26, and the fracture toughness ( $K_{\mathrm{IC}}$ ) was $4.3,2.4$ and 1.7 $\mathrm{MPa} \cdot \mathrm{m}^{1 / 2}$, respectively. These tendencies correspond to a decrease of the glass phase in the grain boundary. The fracture modes of the grains in the fatigue fracture surface for $71 \mathrm{~A}$ was intergranular fracture in equiaxial crystals and transgranular fracture broken in the rod-like crystals, for 72A intergranular fracture in equiaxial crystals and transgranular fracture broken in slightly remained rod-like crystals, and for $74 \mathrm{~A}$ only intergranular fracture. The fracture mode in the catastrophic fracture surface was transgranular for $71 \mathrm{~A}, 72 \mathrm{~A}$ and $74 \mathrm{~A}$. It was considered that the fracture toughness of mullite at $1200^{\circ} \mathrm{C}$ increased with a decrease of $\mathrm{Al}_{2} \mathrm{O}_{3}$ content because the crack tip became blunter by increasing the glass phase.
\end{abstract}

Key=words: Millite, Fatigue, Static fatigue, Slow crack growth, Crack growth parameter, Fracture toughness, Fracture surface, Fracture mode

\section{Introduction}

High purity mullite ceramics ${ }^{1)-3}$ ) have received considerable attention for structural applications in high temperatures because they have excellent high temperature properties with about twice the strength of high purity alumina. We have previously measured the creep in mullite ceramics at 1300 to $1500^{\circ} \mathrm{C}$ and have reported that the creep rate of $74 \mathrm{wt} \% \mathrm{Al}_{2} \mathrm{O}_{3}$ mullite was very little even at $1400^{\circ} \mathrm{C}^{4)-6)}$ If mullite ceramics are used in high temperature, revealing the mechanism of the degradation of strength under stress (the fatigue behavior) and the creep behavior is important.

In this study, the fatigue behavior of mullite containing 71,72 and $74 \mathrm{wt} \% \mathrm{Al}_{2} \mathrm{O}_{3}$ was measured, and the fracture toughness was evaluated from the slow crack growth region magnitude (fatigue fracture sur- face) combined with the applied stress. Furthermore, the relation between their properties and microstructures was considered.

\section{Experimental procedure}

Mullite powder containing 71,72 and $74 \mathrm{wt} \%$ $\mathrm{Al}_{2} \mathrm{O}_{3}$ (hereafter referred to as $71 \mathrm{~A}, 72 \mathrm{~A}$ and $74 \mathrm{~A}$, respectively) prepared by a coprecipitation method using an aqueous solution of $\mathrm{Al}\left(\mathrm{NO}_{3}\right)_{3}$ and colloidal $\mathrm{SiO}_{2}{ }^{7)}$ was compacted isostatically at $300 \mathrm{MPa}$. The compacted specimens were sintered at $1650^{\circ} \mathrm{C}$ in air. The sintered specimens were ground to rectangular bars of $3 \times 4 \times 40 \mathrm{~mm}$ with a diamond wheel. The average grain size of $71 \mathrm{~A}, 72 \mathrm{~A}$ and $74 \mathrm{~A}$ was $2.2,1.6$, and $2.4 \mu \mathrm{m}$, respectively.

Previous papers have already reported the microstructure characteristics of these specimens.4),5) Specimens $71 \mathrm{~A}, 72 \mathrm{~A}$ and $74 \mathrm{~A}$ consisted of fine equiaxial crystals and rod-like crystals, fine equiaxial crystals and slightly remained rod-like crystals, and only equiaxial crystals, respectively.4),5) It has been already observed by the transmission electron microscope (TEM) that the glass phase was absent in 74 wt \%-mullite but present in the grain boundary of mullite containing less than $72 \mathrm{wt} \% \mathrm{Al}_{2} \mathrm{O}_{3}$. ${ }^{5)}$

Fatigue behavior was measured by the static fatigue technique. ${ }^{8)-10)}$ The time-to-failure was measured at several stresses applied by a three-point bending fixture with a span of $30 \mathrm{~mm}$. The fracture toughness was evaluated from the slow crack growth magnitude in the fracture surface and the applied stress by a controlled surface flaw technique. ${ }^{11)}$

\section{Experimental results}

\subsection{Static fatigue}

Static fatigue is defined as the degradation behavior of strength under an applied stress. Slow crack growth is responsible for fatigue in ceramics and the time-to-failure $\left(t_{\mathrm{f}}\right)$ at a constant applied stress $(\sigma)$ is expressed as:8)-10),12)

$$
t_{\mathrm{f}}=B_{1} \sigma^{-N}
$$

where $N$ is the crack growth parameter and $B_{1}$ is a constant value. 
If the relation between the applied stress and the time-to-failure is plotted in a logarithmic coordination, the gradient corresponds to the $N$ value. The $N$ value magnitude indicates the fatigue behavior. The larger the $N$ value is, the larger the fatigue resistance is. The $N$ value was calculated by the least-square method. Brittle fracture occurring immediately after elastic deformation is a prerequisite for applying the Eq. (1). As previously reported, the creep rate became lower at $1400^{\circ} \mathrm{C}$ for $74 \mathrm{~A}$ and $1350^{\circ} \mathrm{C}$ for $71 \mathrm{~A} .{ }^{4), 5)}$ It is estimated that creep behavior is negligible in this study because the fatigue measurement was performed at $1200^{\circ} \mathrm{C}$.

Generally, the strength of ceramics shows a large scatter, because they are sensitive to the magnitude of flaws in a sintered body. The fatigue behavior for $71 \mathrm{~A}$ was measured for specimens precracked by a Vickers indenter and uncracked specimens. Figure 1 shows the relation between the applied stress and the time-to-failure for 71A. The symbol " $\square$ " shows the results for specimens not precracked and their values were remarkably scattered on the lower side of the time-to-failure than line A. However, if the applied stresses was below $204 \mathrm{MPa}$, the value was between lines $\mathrm{A}$ and $\mathrm{B}$, and the scatter was small. The symbol " shows the results for specimens precracked by a Vickers indenter at $300 \mathrm{~g}$. Some of the values existed between lines A and B. The symbol " $\bigcirc$ " shows the results for the Vickers indenter at $500 \mathrm{~g}$. The values were independent of the scatters for specimens not precracked. The $N$ value for specimens precracked by the Vickers indenter at $500 \mathrm{~g}$ was 17.

Figure 2 shows the relation between the applied stress and the time-to-failure for $72 \mathrm{~A}$. The symbols " $\bigcirc$ " and "O" are the results for specimens precracked by the Vickers and the Knoop indenters at $500 \mathrm{~g}$, respectively. Results for both indenters were not remarkably different in their scatters. The $N$ values were 23 for the Vickers and 24 for the Knoop indenters.

Figure 3 shows the relation between the applied stress and the time-to-failure for $74 \mathrm{~A}$. The symbol "O" is for the Knoop indenter at $500 \mathrm{~g}$. The relation between $\log \sigma$ and $\log t_{\mathrm{f}}$ was linear above the applied stresses of about $108 \mathrm{MPa}$, but the specimens were not broken below stresses of about $106 \mathrm{MPa}$, even if they were held for a long time. The $N$ value from the linear relation was 26 . The $74 \mathrm{~A}$ specimen unbroken after $2 \mathrm{~h}$ at applied stresses between 107 and 108 $\mathrm{MPa}$ was not broken, even if held for 1 to $10 \mathrm{~d}$. The relation between $\log \sigma$ and $\log t_{\mathrm{f}}$ became horizontal at applied stresses of 107 to $108 \mathrm{MPa}$ and showed a tendency equal to fatigue limit. The static fatigue at $200^{\circ} \mathrm{C}$ for $2 \mathrm{~mol} \% \mathrm{Y}_{2} \mathrm{O}_{3}$-containing tetragonal zirconia polycrystals showed the horizontal behavior in the relation between $\log \sigma$ and $\log t_{\mathrm{f}}{ }^{13)}$

The symbol " $\bigcirc$ " in Fig. 3 shows the relation between $\log \sigma$ and $\log t_{\mathrm{f}}$ measured after holding for

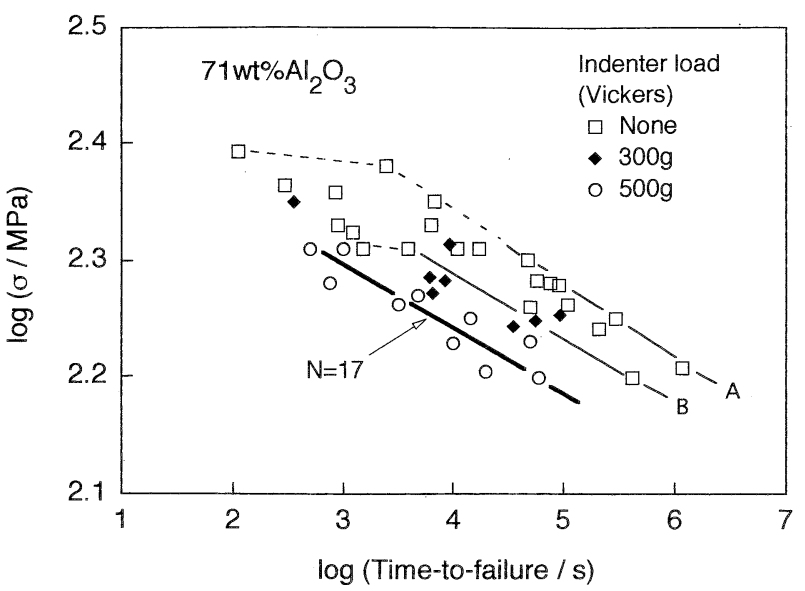

Fig. 1. The relation between the time-to-failure and the applied stress $\left(\sigma_{\mathrm{t}}\right)$ at $1200^{\circ} \mathrm{C}$ for $71 \mathrm{wt} \% \mathrm{Al}_{2} \mathrm{O}_{3}$-mullite. “ $\square$ ” is not precracked. " $\bullet$ " and “ $\bigcirc$ " are precracked by a Vickers indenter at 300 and $500 \mathrm{~g}$, respectively.

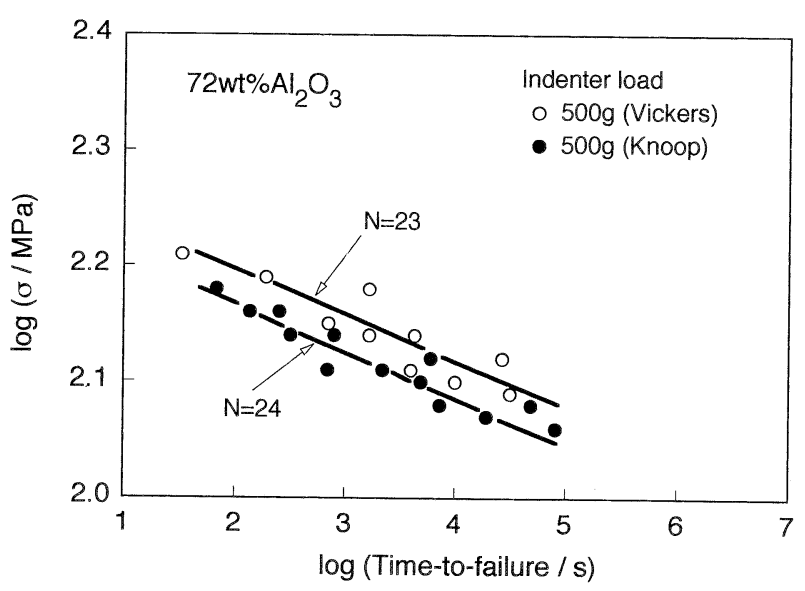

Fig. 2. The relation between the time-to-failure and the applied stress $\left(\sigma_{\mathrm{t}}\right)$ at $1200^{\circ} \mathrm{C}$ for $72 \mathrm{wt} \% \mathrm{Al}_{2} \mathrm{O}_{3}$-mullite. " $\bigcirc$ " and " $O$ " are precracked by a Vickers and a Knoop indenter at $500 \mathrm{~g}$, respectively.

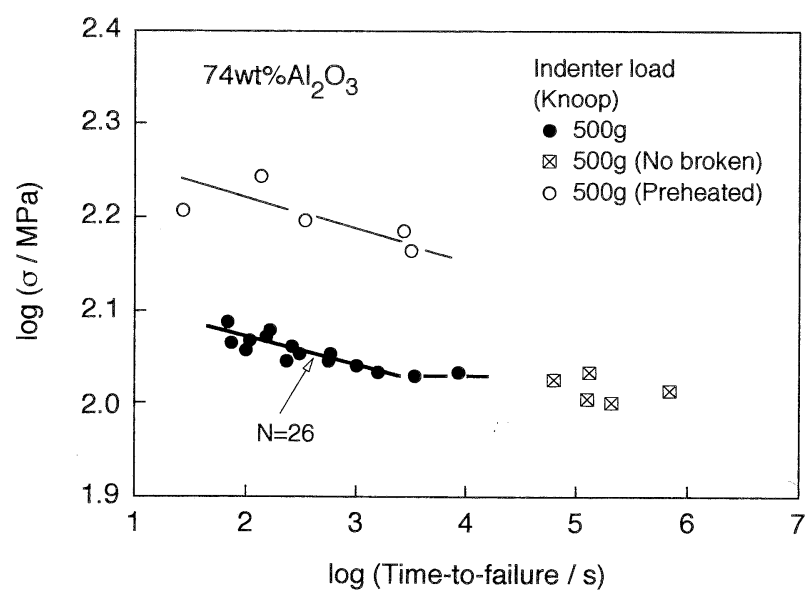

Fig. 3. The relation between the time-to-failure and the applied stress $\left(\sigma_{\mathrm{t}}\right)$ at $1200^{\circ} \mathrm{C}$ for $74 \mathrm{wt} \% \mathrm{Al}_{2} \mathrm{O}_{3}$-mullite precracked by a Knoop indenter at $500 \mathrm{~g}$. "O" is broken and " $\square$ " is not broken by the static fatigue measurement. " $\bigcirc$ " is measured after holding for $1 \mathrm{~d}$ at the applied stress of $105 \mathrm{MPa}$. 
$1 \mathrm{~d}$ at an applied stress of $105 \mathrm{MPa}$ below the stress showing the horizontal behavior. This showed that strength increased by preheating for $1 \mathrm{~d}$ at $1200^{\circ} \mathrm{C}$. However, the gradient ( $N$ value) obtained from the relation was similar to that in specimens not preheated.

In summary, $N$ values increased with increasing $\mathrm{Al}_{2} \mathrm{O}_{3}$ and the resistance to fatigue became much better. This relation between the $N$ value and the $\mathrm{Al}_{2} \mathrm{O}_{3}$ content corresponds to the relation between the glass phase and the $\mathrm{Al}_{2} \mathrm{O}_{3}$ content in mullite.

3.2 Observation of fracture surface and fracture toughness

Figures 4 and 5 show the fracture surface of $71 \mathrm{~A}$ after measuring fatigue behavior. Figure 4 is for specimen not precracked. The applied stress was $161 \mathrm{MPa}$ and the time-to-failure was $13 \mathrm{~d} 15 \mathrm{~h}$ and

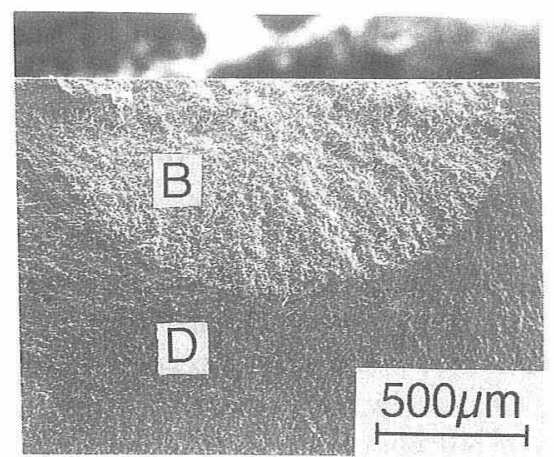

Fig. 4. The fracture surface of $71 \mathrm{wt} \% \mathrm{Al}_{2} \mathrm{O}_{3}$-mullite not precracked. The applied stress was $161 \mathrm{MPa}$ and the time-tofailure was $13 \mathrm{~d} 15 \mathrm{~h}$ and $52 \mathrm{~min}$. "B" and "D" show the slow crack growth region and the catastrophic fracture surface.
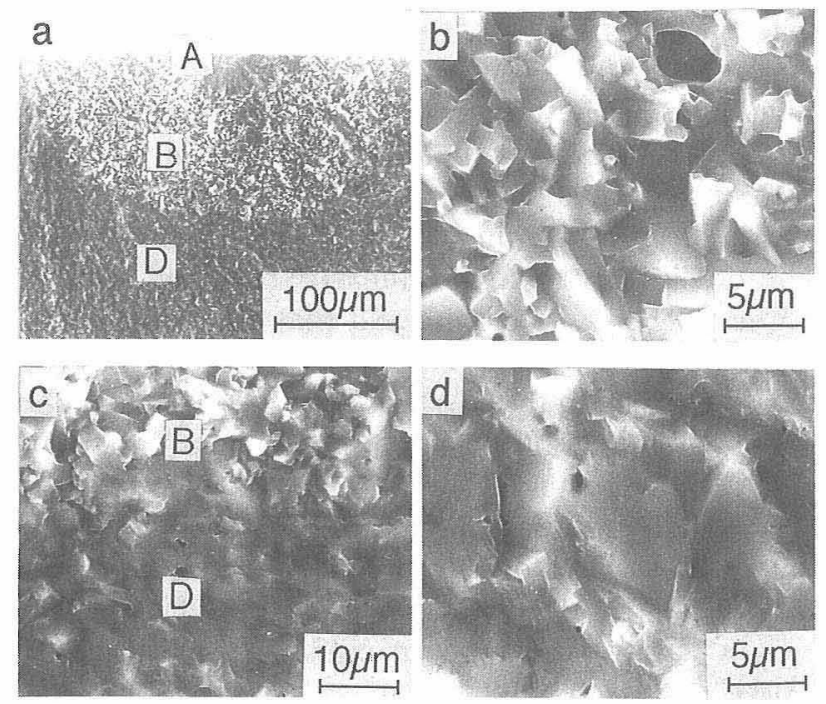

Fig. 5. The fracture surface of $71 \mathrm{wt} \% \mathrm{Al}_{2} \mathrm{O}_{3}-$ mullite precracked by a Vickers indenter at $500 \mathrm{~g}$. The applied stress was $183 \mathrm{MPa}$ and the time-to-failure was $53 \mathrm{~min}$ and $4 \mathrm{~s}$. "A", "B" and "D" in (a) show the Vickers indentation, the slow crack growth region and the catastrophic fracture surfaces, respectively. (b) and (d) are enlarged photographs corresponding to regions " $B$ " and " $D$ " in (a), and (c) shows the boundary of them.
$52 \mathrm{~min}$. Figure 5 is for specimens precracked with a Vickers indenter at $500 \mathrm{~g}$. The applied stress was $183 \mathrm{MPa}$, and the time-to-failure was $53 \mathrm{~min}$ and $4 \mathrm{~s}$.

The slow crack growth region spread semielliptical from the origin and the catastrophic fracture surface followed. The origin was a natural flaw on the specimen surface for Fig. 4 and the Vickers indentation for Fig. 5. Figures 5(b) and (d) are enlarged photographs of the slow crack growth region (region B) and the catastrophic fracture region (region D) in Fig. 5(a), respectively. Figure 5(c) shows the boundary of the slow crack growth and the catastrophic fracture surface regions. The fracture mode of grains in the slow crack growth region was intergranular fracture in equiaxial crystals and transgranular fracture broken in the rod-like crystals. However, the fracture mode in the catastrophic fracture region was transgranular.

Figures 6 and 7 show the fracture surfaces of $72 \mathrm{~A}$ precracked by a Vickers indenter at $500 \mathrm{~g}$ and $74 \mathrm{~A}$ precracked by a Knoop indenter at $500 \mathrm{~g}$, respective1y. They show the fracture surfaces broken after holding $22 \mathrm{~h} 40 \mathrm{~min}$ and $58 \mathrm{~s}$ at an applied stress of $115 \mathrm{MPa}$, and $9 \mathrm{~min}$ and $20 \mathrm{~s}$ at an applied stress of $110 \mathrm{MPa}$, respectively.

The slow crack growth region spread semielliptical from the Vickers or the Knoop indentation, and the catastrophic fracture surface followed similar to the 71A-mullite. Figures (b) and (d) in Figs. 6 and 7 are enlarged photographs of the slow crack growth (region B) and the catastrophic fracture regions (region D), respectively. Figures 6(c) and 7(c) show the boundary of the slow crack growth and the catastrophic fracture surface regions. The fracture
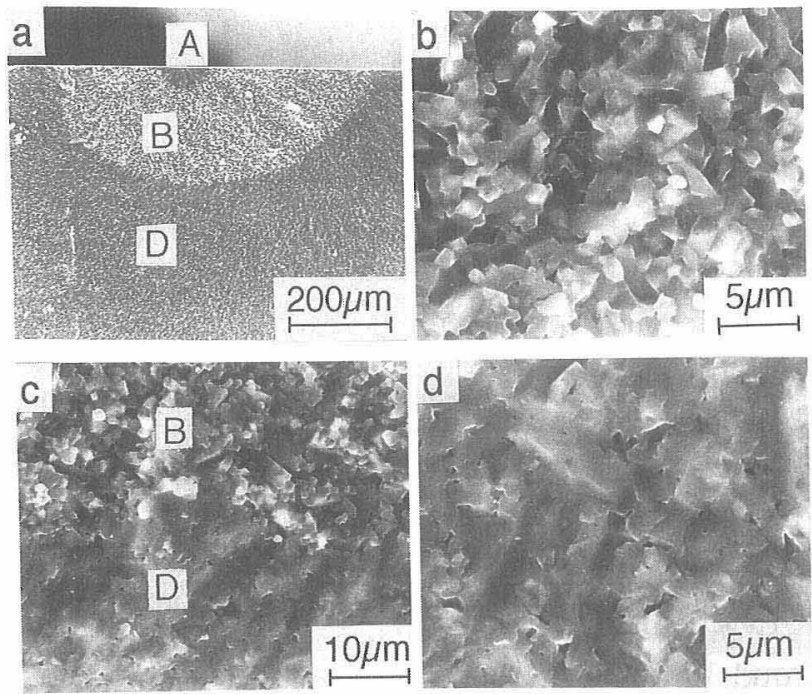

Fig. 6. The fracture surface of $72 \mathrm{wt} \% \mathrm{Al}_{2} \mathrm{O}_{3}$-mullite precracked by a Vickers indenter at $500 \mathrm{~g}$. The applied stress was $115 \mathrm{MPa}$ and the time-to-failure was $22 \mathrm{~h} 40 \mathrm{~min}$ and $58 \mathrm{~s}$. "A" "B" and "D" in (a) show the Vickers indentation, the slow crack growth region and the catastrophic fracture surface, respectively. (b) and (d) are enlarged photographs corresponding to region $\mathrm{B}$ and $\mathrm{D}$ in (a), and (c) shows the boundary of them. 

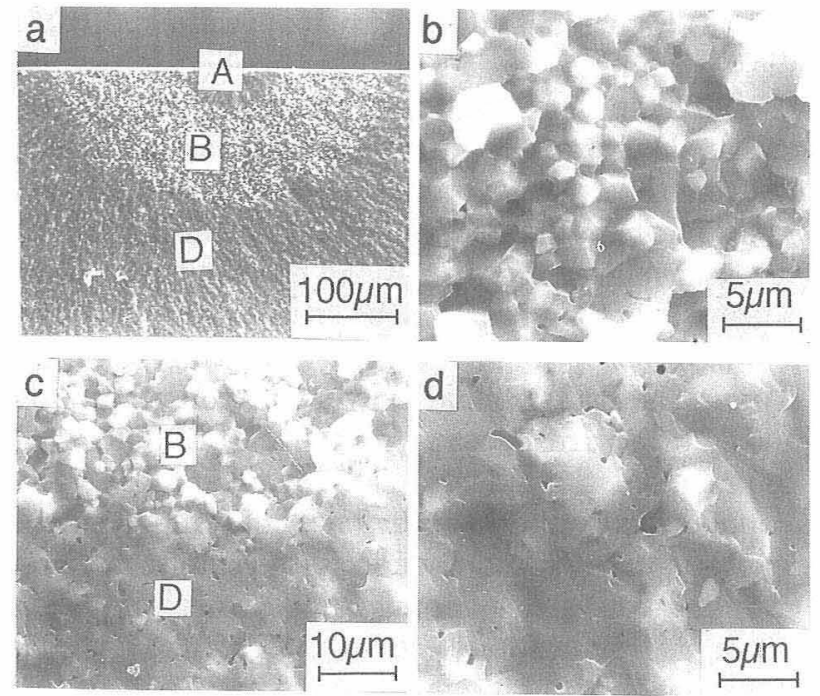

Fig. 7. The fracture surface of $74 \mathrm{wt} \% \mathrm{Al}_{2} \mathrm{O}_{3}$-mullite precracked by a Knoop indenter at $500 \mathrm{~g}$. The applied stress was $110 \mathrm{MPa}$ and the time-to-failure was 9 min and $20 \mathrm{~s}$. "A" "B" and "D" in (a) show the Knoop indentation, the slow crack growth region and the catastrophic fracture surface, respectively. (b) and (d) are enlarged photographs corresponding to region " $\mathrm{B}$ " and " $\mathrm{D}$ " in (a), and (c) shows the boundary of them.

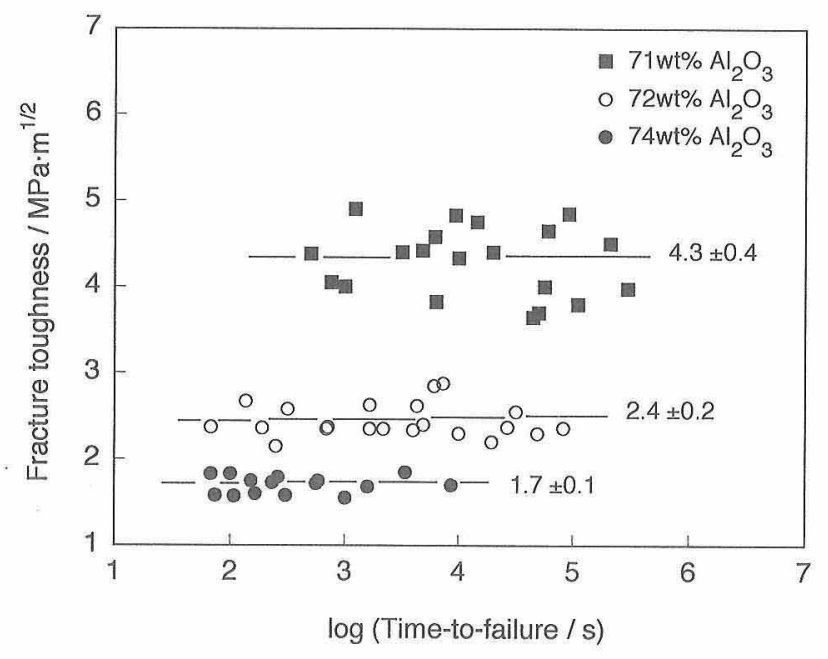

Fig. 8. The fracture toughness of 71,72 and $74 \mathrm{wt} \% \mathrm{Al}_{2} \mathrm{O}_{3}$-mullite as a function of the time-to-failure.

mode of grains in the slow crack growth region of $72 \mathrm{~A}$ was intergranular fracture in equiaxial crystals and transgranular fracture broken in the rod-like crystal. However, the slow crack growth region of $74 \mathrm{~A}$ was intergranular fracture. All the fracture modes in the catastrophic fracture regions in $72 \mathrm{~A}$ and $74 \mathrm{~A}$ were transgranular and similar to $71 \mathrm{~A}$.

The $K_{\text {IC }}$ was evaluated by a controlled surface flaw technique combining the slow crack growth region magnitude with the applied stress. ${ }^{7)}$ Figure 8 shows the results. The $K_{\text {IC }}$ was $4.3,2.4$ and to $1.7 \mathrm{MPa}$. $\mathrm{m}^{1 / 2}$ for 71,72 and $74 \mathrm{wt} \% \mathrm{Al}_{2} \mathrm{O}_{3}$, respectively.

\section{Discussion}

\subsection{Fatigue behavior}

The flaws that exist in sintered bodies are divided into microcracks which exist exclusively along the grain boundaries and macroflaws such as pores developed in the manufacturing process. ${ }^{14), 15)}$ Generally, the strength of a material is scattered, if the pore size is larger than the grain size of the material. Figure 4 shows that the slow crack growth region in $71 \mathrm{~A}$ not precracked has grown from a microcrack on the specimen surface at maximum stress point, and the specimen is broken when the stress intensity factor from the combination of the slow crack growth region magnitude and the applied stress were equal to the critical stress intensity factor (fracture toughness).

A crack developed under an applied stress, that is, the slow crack growth region, is equal to fatigue crack. The fatigue crack magnitude was large in low applied stresses, because the time-to-failure was long. The strength of the specimen not precracked in $71 \mathrm{~A}$ was slightly scattered at low applied stresses because it was controlled by the fatigue crack magnitude and not by the macroflaws such as pores. However, the fatigue crack magnitude was small in high applied stresses, because the time-to-failure was short. The strength of the specimen not precracked in $71 \mathrm{~A}$ was scattered at high applied stresses, because it was controlled not only by fatigue crack but also by macroflaws such as pores. If the flaw produced by the Vickers or the Knoop indenter at $500 \mathrm{~g}$ (Figs. 1, 2 and 3) was used as the initial crack in static fatigue measurement, the scatter of the result was small because the growth of the fatigue crack initiated from the controlled flaw.

It is considered that crack healing arise simultaneously with crack growth, if a stress is applied at a high temperature such as $1200^{\circ} \mathrm{C}$. Figure 3 shows that the relation between the applied stress and the time-to-failure after holding for $1 \mathrm{~d}$ at $105 \mathrm{MPa}$. The relation had shifted to the high strength side because of crack healing. That is, it is estimated that the crack growth in the measurement of static fatigue at $1200^{\circ} \mathrm{C}$ was the result that the crack growth under an applied stress was interrupted by the crack healing resisting to the crack growth. The $74 \mathrm{~A}$ specimens unbroken after $2 \mathrm{~h}$ at applied stresses of 107 to $108 \mathrm{MPa}$ were not broken, even if they were held for 1 to $10 \mathrm{~d}$, because the crack growth at this applied stress is in equilibrium with crack healing at $1200^{\circ} \mathrm{C}$.

The fatigue behavior in oxide ceramics such as $\mathrm{Al}_{2} \mathrm{O}_{3}$ is affected by the glass phase in the grain boundary.5),12) Generally, the $N$ value decreases with increasing the glass phase. In this study, the $N$ value at $1200^{\circ} \mathrm{C}$ decreased with decreasing $\mathrm{Al}_{2} \mathrm{O}_{3}$, that is, increasing the glass phase in the grain boundary. The fatigue behavior of glass or oxide ceramics in room temperature was interpreted by the mechan- 
ism of stress corrosion caused by water vapor. More studies are required to determine whether the fatigue mechanism of mullite ceramics at high temperatures such as $1200^{\circ} \mathrm{C}$ is the same as oxide ceramics in room temperature or not.

\subsection{Fracture toughness}

In the previous paper the glass phase was slightly present in the grain boundary triple point of $72 \mathrm{~A}$, increased in the grain boundary of $71 \mathrm{~A}$ and was absent in $74 \mathrm{~A} .{ }^{5)}$ Figure 8 shows that the $K_{\text {IC }}$ of mullite ceramics at $1200^{\circ} \mathrm{C}$ increased with decreasing $\mathrm{Al}_{2} \mathrm{O}_{3}$. That is, the $K_{\text {IC }}$ of mullite at $1200^{\circ} \mathrm{C}$ increased with increasing glass phase.

The $K_{\text {IC }}$ of these mullite ceramics was about 2 $\mathrm{MPa} \cdot \mathrm{m}^{1 / 2}$ at room temperature. That is, $K_{\text {IC }}$ of $74 \mathrm{~A}$ at $1200^{\circ} \mathrm{C}$ was similar to room temperature. However, the $K_{\mathrm{IC}}$ of $71 \mathrm{~A}$ at $1200^{\circ} \mathrm{C}$ was larger than at room temperature. The similar effects of the glass phase to the $K_{\text {IC }}$ at high temperature was previously reported for $\left.\mathrm{Si}_{3} \mathrm{~N}_{4} \cdot{ }^{16)}, 17\right)$

It is considered that the $K_{\mathrm{IC}}$ of mullite ceramics at $1200^{\circ} \mathrm{C}$ is increased by the glass phase, and the $K_{\text {IC }}$ of mullite containing the glass phase at $1200^{\circ} \mathrm{C}$ is larger than at room temperature because the crack tip becomes blunter by increasing the glass phase.

\section{Conclusions}

The fatigue behavior of mullite ceramics containing 71,72 and $74 \mathrm{wt} \% \mathrm{Al}_{2} \mathrm{O}_{3}(71 \mathrm{~A}, 72 \mathrm{~A}$ and $74 \mathrm{~A})$ was measured at $1200^{\circ} \mathrm{C}$ by the static fatigue technique. The fracture toughness at $1200^{\circ} \mathrm{C}$ was evaluated from the fatigue fracture surface magnitude combined with the applied stress by using the controlled surface flaw technique. Results obtained are as follows:

(1) The crack growth parameter $(N)$ of $71 \mathrm{~A}, 72$ $\mathrm{A}$ and $74 \mathrm{~A}$ was $17,23-24$, and 26 , respectively. The resistance to fatigue increased with increasing $\mathrm{Al}_{2} \mathrm{O}_{3}$. The fracture toughness $\left(K_{\mathrm{IC}}\right)$ of $71 \mathrm{~A}, 72 \mathrm{~A}$ and $74 \mathrm{~A}$ was $4.3,2.4$ and $1.7 \mathrm{MPa} \cdot \mathrm{m}^{1 / 2}$, respectively. These tendencies correspond to a decrease of the glass phase in the grain boundary.

(2) The fracture modes of the grain in the slow crack growth region (fatigue fracture surface) for $71 \mathrm{~A}$ was intergranular fracture in equiaxial crystals and transgranular fracture broken in rod-like crystals, for $72 \mathrm{~A}$ intergranular fracture in equiaxial crys- tals and transgranular fracture broken in slightly remained rod-like crystals, and for $74 \mathrm{~A}$ only intergranular fracture. The fracture mode in the catastrophic fracture surface was transgranular for $71 \mathrm{~A}$, $72 \mathrm{~A}$ and $74 \mathrm{~A}$.

(3) It was considered that the fracture toughness of mullite at $1200^{\circ} \mathrm{C}$ increased with decreasing $\mathrm{Al}_{2} \mathrm{O}_{3}$ content, because the crack tip became blunter by increasing the glass phase.

Acknowledgment The authors would like to thank Professor Mitamura at Saitama University for his help.

\section{References}

1) K. S. Mazdiyasni and L. M. Brown, J. Am. Ceram. Soc., 55, 548-52 (1972).

2) P. A. Lessing, R. S. Gordon and K. S. Mazdiyasni, J. Am. Ceram. Soc., 58, 149 (1975).

3) P. C. Dokko, J. A. Pask and K. S. Mazdiyasni, J. Am. Ceram. Soc., 60, 150-55 (1977).

4) M. Ashizuka, T. Okuno and Y. Kubota, J. Ceram. Soc. Japan, 97, 662-68 (1989).

5) M. Ashizuka, T. Honda and Y. Kubota, J. Ceram. Soc. Japan, 99, 292-95 (1991).

6) M. Ashizuka, T. Honda and Y. Kubota, J. Ceram. Soc. Japan, 99, 357-60 (1991).

7) Y. Kubota and H. Takagi, Proc. Brit. Ceram. Soc., 37, 17988 (1986).

8) A. G. Evans and S. M. Wiederhorn, Inter. J. Fracture, 10, 379-92 (1974).

9) J. E. Ritter and J. N. Humenik, J. Mater. Sci., 14, 626-32 (1979).

10) S. M. Wiederhorn, "Fracture Mechanics of Ceramics, Vol. 2”, Ed. by R. C. Bradt, D. P. H. Hasselman and F. F. Lange, Plenum Press (1974) pp. 613-46.

11) J. J. Petrovic and M. G. Mendiratta, "Fracture Mechanics Applied to Brittle Materials, ASTM STP 678”, Ed. by S. W. Freiman, American Society for Testing and Materials (1979) pp. 83-102.

12) M. Ashizuka, H. Kiyohara, E. Ishida, M. Kuwabara, Y. Kubota and T. Tsukidate, Yogyo-Kyokai-Shi, 94, 432-39 (1986).

13) M. Ashizuka, H. Kiyohara, T. Okuno and Y. Kubota, YogyoKyokai-Shi, 96, 820-24 (1988).

14) A. G. Evans and T. G. Langdon, "Structural Ceramics, in Progress in Materials Science, Vol. 21”, Pergamon Press (1976) pp. 183-202.

15) D. W. Richerson, "Modern Ceramic Engineering”, Marcel Dekker (1982) pp. 76-82.

16) R. K. Govila, J. Am. Ceram. Soc., 63, 319-26 (1980).

17) S. H. Knickerbocker, A. Zangvil and S. D. Brown, J. Am. Ceram. Soc., 68, C99-101 (1985). 